Section Editor

Robert C. Griggs, MD
Editors' Note: In WriteClick this week, Dr. Bej traces the changing names and dominions of the city currently called L'viv, Ukraine, birthplace of Irena Hausmanowa-Petrusewicz, $\mathrm{MD}, \mathrm{PhD}$. In reference to "Cause of death and predictors of mortality in a community-based cohort of people with epilepsy," Drs. Nevalainen and Ansakorpi and authors Sander et al. discuss the relationship between cause of death and epilepsy etiology as well as the concerning increased risk of death from neoplasms in patients with epilepsy.

—Megan Alcauskas, MD, and Robert C. Griggs, MD

IRENA HAUSMANOWA-PETRUSEWICZ, MD, PHD (1917-2015)

Mark D. Bej, Oberlin, OH: Dr. HausmanowaPetrusewicz's In Memoriam mentioned she studied in "Lvov."

A consequence of Europe's frequent changes to national borders (usually via conquest) is that most large cities have multiple names or spellings, depending on the language in use (or imposed). Thus, we have Geneva/Génève/Genf, Vienna/Vienne/Wien, Bratislava/Preßburg/Pozsony, Breslau/Wrozław, and so forth. "Lvov" (Львов) is the Russian version of the name of the city in question, which has never been ethnically Russian.

In the year 1917, in Lemberg (as the city was known then and now to German speakers), Dr. HaumanowaPetrusewicz would have been born an Austrian citizen. With Poland's reconstitution in 1918, the city would then be known as Lwów (roughly pronounced, "Lvoof"). During Soviet control (1939-1941, 1945-1991) "Lvov" was used. The West tended to follow along, using Russian names for all cities in the USSR, local majority ethnicities notwithstanding. Given Ukraine's independence since 1991, "L'viv" (Львів, pronounced "Lveew," with a soft "L") should be used presently.

As such, the use of "Lvov, Poland" in the obituary is anachronistic (and anatopistic). The best construction would be either "Lwów, Poland (now L'viv, Ukraine)" or "L'viv, Ukraine (then Lwów, Poland)."

Author Response: Anna Kaminska, Warsaw, Poland; Paul E. Barkhaus, Milwaukee: In the In Memoriam for Professor Hausmanowa-Petrusewicz, ${ }^{1}$
WriteClick ${ }^{\circledR}$ Editor's Choice

we used the Russian (Lvov) spelling (using the international phonetic alphabet [IPA]) of the city where her parents had originated. Dr. Bej has carefully reviewed the orthographic transmutations of what is currently L'viv, Ukraine. This city's name has undergone several changes in spellings in the past century, commensurate with its changes in sovereignty. However, the variations in the city's name are particularly difficult for those unfamiliar with Cyrillic script and who rely on the IPA for spelling and pronunciation. We agree with Dr. Bej's proposed phrasing of how to refer to this historic center, presumably basing the phrasing on current political sovereignty. Our choice for the spelling ("Lvov"), rather than the Polish spelling "Lwów" was intended to be phonetic as the "w" in Polish is pronounced as a "v."

Dr. Bej's admonition that our usage is "anatopistic" appears somewhat extreme. We infer that he wishes to ensure that the spelling of L'viv is pari passu with its current sovereignty. However, we expostulate that referring to a term or proper noun in another language would be necessarily subject to linguistic opprobrium. Presumably, to a Russian, Lvov (IPA) would still be correct without implying that it is not a Ukrainian city. We have not had any Polish colleagues, or Dr. Bej, object to our use of Warsaw in our article rather than the Polish spelling, Warszawa. Let us rather remember the focus of the article, Professor HausmanowaPetrusewicz, who was a key figure during some of the turbulent historical times to which Dr. Bej refers, and her successful efforts in international cooperation and collaboration in neurology.

(C) 2016 American Academy of Neurology

1. Barkhaus PE, Kaminska A. Irena HausmanowaPetrusewicz, MD, PhD (1917-2015). Neurology 2016;86: 116-117.

\section{CAUSE OF DEATH AND PREDICTORS OF MORTALITY IN A COMMUNITY-BASED COHORT OF PEOPLE WITH EPILEPSY}

Olli Nevalainen, Tampere, Finland; Hanna Ansakorpi, Oulu, Finland: Keezer et al. ${ }^{1}$ mentioned that in addition to the current study, "only one other study has investigated the relationship between epilepsy etiology and causes of death (COD)." They 
cited a cohort study of patients with any kind of first afebrile epileptic seizure, which by definition has a different case mix than a cohort of epilepsy patients. ${ }^{2}$ At least 4 studies have previously published estimates on the relationship between epilepsy etiology and COD. ${ }^{3}$ Indeed, cardiovascular disease and cancer are a major COD in epilepsy, and the excess of deaths from cerebrovascular disease and ischemic heart disease have been associated with symptomatic etiologies of epilepsy. ${ }^{3}$ Keezer et al. also discussed the high death rate from neoplasms in epilepsy. ${ }^{1}$ It is important to note that excess deaths from neoplasms are not only related to symptomatic etiologies. We estimated a $56 \%$ excess in cancer mortality even in individuals with idiopathic/cryptogenic epilepsy. ${ }^{3}$ Apart from potential biases and residual confounding, the impact of lifestyle-related factors and antiepileptic medication should be investigated further. The epidemiology of epilepsy-related mortality was recently reviewed in detail, which is useful for future studies to identify gaps in our current knowledge on the issue. ${ }^{3,4}$

Author Response: Josemir W. Sander, Gail S. Bell, Mark R. Keezer, London: We thank Drs. Nevalainen and Ansakorpi for the comment on our article, ${ }^{1}$ and for continuing to make important contributions to our evolving understanding of premature mortality in epilepsy.

It appears our statement regarding COD and epilepsy etiology was unclear as it seems misinterpreted. We specifically referred to studies that investigated how often these 2 entities are one and the same. None of the studies referenced by Nevalainen et al. ${ }^{3}$ explicitly examined this particular phenomenon. We agree that the one study we cited reports a heterogeneous sample population. ${ }^{2}$ The data we presented, however, were limited to those with a first unprovoked and symptomatic seizure. Nevertheless, we agree that the participants had only a single epileptic seizure. Our article, therefore, appears to be one of the first to investigate the relationship between epilepsy (rather than a first unprovoked seizure) etiology and COD.

We also agree the increased risk of death from neoplastic disease, among those in which this is not the cause of their epilepsy, demands further investigation. Additionally, we report that among the 41 individuals who died of noncerebral neoplasms, only $29 \%$ had metastatic cerebral disease.

C) 2016 American Academy of Neurology

1. Keezer MR, Bell GS, Neligan A, Novy J, Sander JW. Cause of death and predictors of mortality in a community-based cohort of people with epilepsy. Neurology 2016;86:704712.

2. Loiseau J, Picot MC, Loiseau P. Short-term mortality after a first epileptic seizure: a population-based study. Epilepsia 1999;40:1388-1392.

3. Nevalainen O, Simola M, Ansakorpi H, et al. Epilepsy, excess deaths and years of life lost from external causes. Eur J Epidemiol 2016;31:445-453.

4. Nevalainen O, Ansakorpi H, Simola M, et al. Epilepsyrelated clinical characteristics and mortality: a systematic review and meta-analysis. Neurology 2014;83:1968-1977.

\section{BrainPAC}

BrainPAC is the American Academy of Neurology's (AAN) federal political action committee.

- Since its inception, more than 3,300 AAN members have contributed $\$ 1,900,000$ to BrainPAC.

- BrainPAC anticipates contributing $\$ 650,000$ during the 2015-2016 election cycle placing BrainPAC amongst the ranks of other major medical specialties.

- During the 2014 congressional campaign, 89 percent of candidates supported by BrainPAC won their elections.

BrainPAC supports both Democrats and Republicans who support issues important to the practice of neurology and the care of patients with neurologic conditions. US AAN members are invited to learn more at BrainPAC.org. 


\section{Neurology}

\section{Cause of death and predictors of mortality in a community-based cohort of people with epilepsy}

Olli Nevalainen, Josemir W. Sander, Hanna Ansakorpi, et al.

Neurology 2016;87;852-853

DOI 10.1212/01.wnl.0000494744.36250.46

This information is current as of August 22, 2016

Updated Information \& Services

References

Permissions \& Licensing

Reprints including high resolution figures, can be found at: http://www.neurology.org/content/87/8/852.2.full.html

This article cites 4 articles, 0 of which you can access for free at: http://www.neurology.org/content/87/8/852.2.full.html\#\#ref-list-1

Information about reproducing this article in parts (figures,tables) or in its entirety can be found online at:

http://www.neurology.org/misc/about.xhtml\#permissions

Information about ordering reprints can be found online: http://www.neurology.org/misc/addir.xhtml\#reprintsus

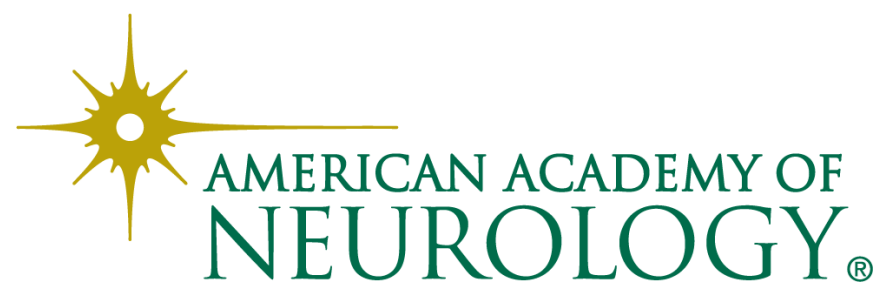

